\title{
SPITZER, Leo. Três poemas sobre o êxtase: Jobn Donne, San Juan de La Cruz, Richard Wagner. São Paulo: Cosac e Naify, 2003.
}

Sergio Alves Peixoto I UFMG

Leo Spitzer foi um dos mais renomados defensores da análise estilística em literatura. Por isso mesmo, desconhecido hoje em dia. Sendo assim, a reunião em livro dessas três análises são extremamente bem-vindas. Especialmente, porque em português.

A importância do presente livro não se resume, entretanto, a uma maior facilidade de acesso ao pensamento desse renomado vienense. Mais relevante que isso, é a possibilidade de se poder repensar o estudo do estilo nos dias de hoje, quando a análise literária se vê invadida por abordagens multiculturais. Nas faculdades de letras brasileiras, muitos dizem que o texto não tem mais importância.

Entretanto, quem conhece a obra de Spitzer e de outros grandes estudiosos do estilo, sabe do valor de tais análises. Principalmente, quando feitas por um fino e arguto crítico, como é o caso de Spitzer. Além de um conhecimento vasto sobre a literatura de seu tempo e de outras épocas, soube ele aliar, a uma base teórica lingüístico-filológica sólida para seu tempo, a percepção 
do valor estético das obras sobre as quais se debruçava. Exatamente o que mais tarde o estruturalista Roman Jakobson exigia de qualquer um que se aventurasse à análise literária de um texto.

Antes de iniciar propriamente as análises, Spitzer nos diz o porquê da escolha dos textos. Dessa forma, acaba indiciando o objetivo que vai perseguir:

Tomemos três poemas que tratam mais ou menos do mesmo tema - a união extática do eu humano com algo que lhe é exterior -, de modo a estudar a transformação mágica por que passam as palavras de uma certa língua às mãos de poetas que lograram fazer de suas experiências íntimas uma realidade poética para o leitor. (p.40)

O primeiro texto a ser analisado é o antológico poema "O êxtase", de John Donne. Pouco a pouco, valendo-se das palavras usadas pelo poeta, suas reincidências, sua organização no verso e, no verso, observando as sonoridades e sua função precípua, Spitzer mostra ao leitor como o poeta fala de um êxtase de almas que, unidas fora do corpo, a ele voltam para a consumação de um amor ainda e sempre espiritual. O corpo não atrapalha a união das almas, o êxtase dos sentidos; pelo contrário, serve de ponte para que esse êxtase aconteça. Mas a união das almas é princípio basilar.

Uma das afirmações sobre o poema e sobre a "filosofia" de Donne é exemplar, na medida em que relaciona a produção do poema em si e o que está ao redor dele, mostrando, diferentemente do que se esperava de um adepto da estilística, que texto e contexto não podem ser dissociados, como mais tarde quiseram provar radicalmente os seguidores do Formalismo Russo e do Estruturalismo.

...sentimos de alguma maneira que o próprio Donne, a despeito de sua tentativa de justificação da carne, tinha mais convicção íntima da realidade e da beleza da união espiritual do que da necessidade do corpo para essa união. É possível que a índole basicamente protestante de Donne seja responsável por essa atitude contraditória. Pois o distanciamento do corpo é característico do protestantismo: na fé judaica, os direitos do corpo coexistem com as exigências que o Criador impôs à alma humana, ao passo que, no catolicismo, se ergue uma ponte entre corpo e alma por meio do sacramento no qual Cristo se torna presente na união corpórea com os fiéis (...) No monumento protestante que Donne ergue à união 
mística, as figuras que encarnam essa união trazem as marcas de uma mão mais firme do que o pedestal de barro que as suporta. (.50-51)

O segundo poema a ser analisado é também o antológico "Em uma noite escura", do místico espanhol San Juan de La Cruz.

A diferença básica que Spitzer vê entre este poema e o de Donne é que San Juan fala de uma união com o divino, metaforizada como uma relação entre alma e corpo. Das três análises, essa é a mais extensa, talvez porque feita em comparação com a anterior. Enquanto o êxtase humano se dá no poema de Donne a partir do corpo, para o extrapolar, no texto do santo espanhol, esse êxtase precisa do homem para que o divino se manifeste.

A última obra a ser estudada não é, na verdade, um poema, ou melhor, não foi escrito com esse objetivo. Faz parte do libreto de Tristão $e$ Isolda, de Wagner. Trata-se do monólogo que encerra a ópera, quando a heroína romântica em êxtase voluptuoso deixa-se morrer de amor, fundindo-se no éter em que Tristão, a seus pés, acabara de penetrar. A diferença entre o tratamento dado ao amor por San Juan e Wagner é realçada por Spitzer:

Já mencionamos várias diferenças de detalhe entre os poemas espanhol e alemão; vemos agora que são diametralmente opostos em seu tratamento do amor. Para glorificar o erotismo, Wagner eleva-o a um novo misticismo; San Juan de la Cruz glorifica (isto é, torna efetiva) a união mística e espiritual ao trazê-la para a carne. O universo de Wagner é panteísta e pan-erótico; o mundo de San Juan de la Cruz é orientado pelo amor divino.

Para os Padres da Igreja, o amor erótico era apenas um reflexo vil do amor a Deus, mas para Wagner, freudiano antes de Freud, o erotismo é a fonte de todos os tipos de amor. (p.92-93)

A abordagem estilística de Leo Spitzer não perdeu sua força com o decorrer do tempo e com as novas formas de se abordar um texto. Trata-se, ainda hoje, de uma permanente redescoberta do que mais tarde Roland Barthes chamou de literariedade. 